УДК 332.3

Шворак Анатолій,

доктор економічних наук, професор,

Східносвропейский національний університет імені Лесі Українки, завідувач кафедри обліку і аудиту, м Луцьк; ORCID ID: 0000-0003-2077-5308 e-mail: ams95@ukr.net

https://doi.org/10.29038/2411-4014-2020-03-130-135

\title{
СХЕМИ ПРОСТОРОВОГО ПЛАНУВАННЯ ГРОМАД - ОСНОВА РОЗВИТКУ СІЛЬСЬКИХ ТЕРИТОРІЙ
}

\begin{abstract}
Анотація. У статті проаналізовано основні проблеми розвитку сільських територій в умовах децентралізації з урахуванням сучасних реалій. На основі проведеного дослідження сформульовано основні напрямки розвитку та відродження сільських територій. Запропоновано рівневу ієрархію проектної документації. Нинішній етап соціального розвитку сільських територій чинності зміни способу сільськогосподарського виробництва та впровадження промислових технологій вирощування сільськогосподарських культур i догляду за худобою характеризується поступовим відмиранням "неперспективних" сільських поселень. Комплексний план просторового розвитку об 'єднаних територіальних громад має стати дорожньою картою розвитку сільських територій. Вирішення проблем розвитку сільських територій повинні включати такі заходи: формування нормативно-правової бази у сфері зайнятості сільського населення, створення потужної дорадчої служби, професійно освітню підготовку кадрів, яка підвищить якість робочої сили, що дозволить зберегти і створити нові робочі місця, сприятиме розвитку підприємництва та самостійній зайнятості населення
\end{abstract}

Ключові слова: сільські території, адміністративно-територіальна реформа, сільськогосподарські вгіддя, охорона земель, фермерські господарства, зайнятість населення.

\section{Шворак Анатолий, доктор экономических наук, профессор, Восточноевропейский национальный университет имени Леси Украинки, кафедра учета и аудита, г. Луцк}

\section{СХЕМЫ ПРОСТРАНСТВЕННОГО ПЛАНИРОВАНИЯ ОБЩИН - ОСНОВА РАЗВИТИЯ СЕЛЬСКИХ ТЕРРИТОРИЙ}

Анотация. В статье проанализированы основные проблемы развития сельских территорий в условиях децентрализации с учетом современных реалий.Сельские территории традиционно занимали особенное место в формировании демографического, экономического, ресурснопроизводственного и социальногуманитарного потенциала Украины. Нынешний этап социального развития сельских территорий в силу изменения способа сельскохозяйственного производства и внедрения промышленных технологий выращивания сельскохозяйственных культур и ухода за скотом характеризуется постепенным отмиранием “неперспективных" сельских поселений. Комплексный план пространственного развития объединенных территориальных общин должен стать дорожной картой развития сельских территорий. Решение проблем развития сельских территорий должны включать следующие меры: формирование нормативно-правовой базы в сфере занятости сельского населения, создание мощной консультационной службы, профессиональнообразовательную подготовку кадров, которая повысит качество рабочей силы, что позволит сберечь и создать новые рабочие места, будет способствовать развитию предпринимательства и самостоятельной занятости населения.

Ключевые слова: сельские территории, административно-территориальная реформа, сельскохозяйственные угодья, охрана земель, фермерские хозяйства, занятость населения.

Shvorak Anatoliy, Doctor of Economics, Professor, Lesya Ukrainka Eastern Europen National University, 


\section{SCHEMES OF SPATIAL PLANNING OF COMMUNITIES - THE BASIS OF DEVELOPMENT OF RURAL TERRITORIES}

The article analyses the main problems of development of rural territories in the conditions of decentralization concerning modern realities. Rural territories traditionally took special place in the formation of demographic, economic, resource-production and social-humanitarian potential of Ukraine. The present stage of social development of rural territories concerning change of the method of agricultural production and introduction of industrial technologies of growing agricultural crops and cattle care is characterized by the gradual extinction of "nonperspective" rural settlements The complex plan of spatial development of united territorial communities must become the road map of rural territories development. The solving of rural territories development problems must include the following measures: the formation of regulatory framework in the sphere of rural population employment, the creating of powerful consulting service, professional-education training of personnel, which will increase the quality of workforce, that will allow to save and create the new working places, will promote the development of entrepreneurship and independent employment of population.

Key words: rural territories, administrative-territorial reform, agricultural grounds, land protection, farms, population employment.

Постановка проблеми. Сільські території традиційно займали особливе місце у формуванні демографічного, економічного, ресурсновиробничого і соціальногуманітарного потенціалу України. Винятковою є роль сільських територій у вирішенні проблеми забезпечення продовольчої безпеки країни та нарощуванні експортного потенціалу, який сьогодні істотним чином впливає на механізм формування валютних надходжень держави. Як показали проведені дослідження, найбільш гострими проблемами розвитку сільських територій на даний час такі:

1. Низький рівень оплати праці сільського населення, обмеження можливостей населення сільських територій до зростання рівня доходів призвела до значних міграційних процесів та зниження трудового та інтелектуального потенціалу села;

2. Руйнування соціальної інфраструктури в сільській місцевості призвела до погіршення соціальних умов (освіта, медицина, культура, побутове обслуговування), скорочення робочих місць та зниження рівня престижності сільської праці;

3. Відсутність держпідтримки особистих селянських господарств та фермерів створило непривабливі умови для формування механізму інвестиційного донорства сільських територій із боку вітчизняних та іноземних суб'єктів. 34 млрд грн спецдотації в 2017 році отримав 1,4 млрд. грн "Миронівський хлібопродукт" і 517 млн грн - "Укрлендфармінг". Залишок у 2,08 млрд грн розділили між собою 1704 компанії.

4. Незавершеність земельної реформи призвели до розвитку тіньових схем купівлі- продажу земель сільськогосподарського призначення та запровадження ринку земель на умовах неприйнятних для більшості жителів сільської місцевості, які збільшують можливості агрохолдингів та обмежують можливості селян, створює стратегічну небезпеку розвитку сільських територій;

5. Застарілий стереотипний підхід до сільських територій як виключно просторової бази сільськогосподарського виробництва та відсутність механізму ефективної взаємодії органів влади на державному, регіональному, місцевому рівнях та агроформувань, щодо напрямів розвитку сільських територій та механізмів їх реалізації.

Мета статті - узагальнити виклад основних концептуальних підходів до планування комплексного розвитку сільських територій і організації конкурентоспроможного агропромислового виробництва в умовах адміністративно-територіальної реформи та децентралізації владних повноважень.

Виклад основного матеріалу дослідження. Нинішній етап соціального розвитку сільських територій в силу зміни способу сільськогосподарського виробництва та впровадження промислових технологій вирощування сільськогосподарських культур і догляду за худобою характеризується поступовим відмиранням «неперспективних» сільських поселень. Офіційна статистика відображає 
цей процес не в повному масштабі: за даними Держстату, із 1990 по 2018 роки зникли 3 карти України 426 сільських населених пунктів. Однак справжня кількість «вимерлих» сіл набагато більша: 2014-го 369 безлюдних сіл просто не були зняті з державного обліку (Інститут демографії та соціальних досліджень НАНУ, 2017). На межі зникнення перебуває ще 4684 села, де станом на 2015 рік мешкало до 50 осіб у кожному. Існує чітко виражена тенденція залежності людяності сільських населених пунктів від наявності робочих місць: суб'єкти господарської діяльності відсутні у 91,4\% сільських населених пунктів із чисельністю жителів до 49 осіб. Майже у половині сільських населених пунктів відсутні суб'єкти сільськогосподарської діяльності, які формують робочі місця, що в основному забезпечують доходи сільських жителів та надходжень до місцевих бюджетів. Селоутворюючими елементами для більшості поселень, крім приміських, є сільгоспвиробництво, орна земля, пасовища, сади та ландшафтний потенціал території. За нинішнього стану наявності трудових ресурсів було б доцільно забезпечити норматив створення одного робочого місця на кожні 15-20 гектарів землекористування для сільгосппідприємств або напрацювати механізм сплати компенсацій для створення робочих місць у громадах та сільських, селищних радах за винятком фермерських господарств площею в межах 100 гектарів. Аналогічні нормативи діють у країнах Європи, особливо в регіонах Франції. Зберегти існуючу систему розселення непросто, але відновити і знову освоїти території дорожче в сотні разів. Раціональне використання природних, а особливо земельних ресурсів, вимагає збереження існуючих систем розселення та поселенської мережі. Ці проблеми регулюються відповідними нормативними актами:

- Законом Про регулювання містобудівної діяльності статтею1п.12 де відмічено, що схеми планування території на регіональному рівні - планувальна документація, яка розробляється у розвиток Генеральної схеми планування території України та визначає принципові вирішення розвитку, планування, забудови, використання територій адміністративно-територіальних одиниць та їх окремих частин [1];

- статтею 45 Закону Про землеустрій сказано- схеми землеустрою і техніко-економічні обгрунтування використання та охорони земель адміністративно-територіальних одиниць розробляються 3 метою визначення перспективи щодо використання та охорони земель, для підготовки обгрунтованих пропозицій у галузі земельних відносин, організації раціонального використання та охорони земель, перерозподілу земель з урахуванням потреби сільського, лісового та водного господарств, розвитку сіл, селищ, міст, територій оздоровчого, рекреаційного, історикокультурного призначення, природно-заповідного фонду та іншого природоохоронного призначення тощо [2];

- статтею 181 Земельного кодексу України яка константує що, землеустрій - це сукупність соціально-економічних та екологічних заходів, спрямованих на регулювання земельних відносин та раціональної організації території адміністративно-територіальних одиниць, суб'єктів господарювання, що здійснюються під впливом суспільно-виробничих відносин і розвитку продуктивних сил [3].

Враховуючи спільні задачі містобудівного та земельного законодавства Верховна Рада України прийняла у першому читанні відповідний законопроект № 2280 щодо планування використання земель. Законопроектом запроваджується можливість складання схем просторового планування території громади як інструменту комплексного управління у галузі використання іiі земель, встановлення їх призначення, зонування території та визначення напрямів іiі збалансованого розвитку. Даним законопроектом передбачається внесення змін до Земельного кодексу та Закону «Про регулювання містобудівної діяльності». Завдяки цьому сформується новий тип містобудівної документації, - комплексний план просторового розвитку об'єднаних територіальних громад, який буде одночасно містобудівною документацією і документацією із землеустрою на місцевому рівні. Дана документація дасть змогу комплексно вирішити відповідні завдання:

- визначатиме планувальну організацію, функціональне призначення території, основні принципи i напрямки формування єдиної системи громадського обслуговування населення, дорожньої мережі, інженерно-транспортної інфраструктури, інженерної підготовки і благоустрою, цивільного захисту території та населення від небезпечних природних і техногенних процесів, охорони і збереження культурної спадщини та традиційного характеру середовища населених пунктів; 
- еколого-економічне обгрунтування використання та охорони земель, схему запланованих заходів щодо раціонального використання та охорони земель, та інших компонентів навколишнього природного середовища, а також послідовність реалізації рішень, у тому числі етапність освоєння території;

- встановлюватиме черговість розроблення генеральних планів окремих міст громади та детальних планів території або безпосередньо містити відповідні планувальні рішення зазначеної містобудівної документації; встановлювати функціональне призначення, вимоги до забудови окремих територій (функціональних зон) території всієї громади, їх ландшафтної організації;

- створення прозорого та неконфліктного механізму врахування громадських та приватних інтересів через прозорі громадські обговорення;

- розробляється у розвиток регіональної та Генеральної схеми планування території України ;

- включатиме пропозиції раніше розробленої проектної документації [4]коли вона затверджена раніше, i їх планувальні рішення узгоджуються із таким комплексним планом.

Прийняття даного законопроекту дасть можливість зменшити витрати часу і коштів на розробку проектної документації та формування агровиробничої інфраструктури, запрвадження вирбничих стандартів агровиробничої діяльності дасть змогу науково обгрунтовати норми, нормативи й вимоги щодо забезпечення сталого розвитку сільського господарства 3 урахуванням природно-економічних і територіальних особливостей його ведення на тій чи іншій сільській території і які включають:

- Дотримання еколого-економічного обгрунтування сівозмін для відповідних природокліматичних зон;

- Оптимальних показників щільності сільськогосподарських тварин (умовного поголівя) на природнокормові угіддя;

- Нормативі екологобезпечного використання земель.

Рівень дотримання цих стандартів можна розглядати як рівень освоєння сільськогосподарського та виробничого потенціалу території, оскільки через їх дотримання по суті впроваджується раціональне, екологобезпечне ведення агровиробництва, оптимізується структура виробництва, поглиблюється агровиробнича спеціалізація сільських територій.

Подібна практика існує також в країнах ЄС у вигляді Кодеків доброї (належної) сільськогосподарської практики й подібни х їм деректив і системи державного і громадського контролю за їх дотриманням [4].

Для прикладу проаналізуємо використання природних кормових угідь, яке завжди було актуальним для сільського господарства України. Особливо гостро це питання постає в аспекті тваринництва, бо кількість та якість отриманої продукції залежить від якісного стану, характеру і умов використання природно-кормових угідь. Проведення відповідних заходів призведе до імпортозаміщення продукції тваринництва, що дасть можливість створити в сільськогосподарських підприємствах додатково більше 34 тисяч робочих місць при продуктивністі праці в тваринництві у сільськогосподарських підприємствах - 237990грн $\quad(18$ х 0,4554: 0,000238=34442) та збільшить надходження коштів в особисті селянські господарства на 9,8 мільярда гривень. Дані заходи дадуть можливість покращити соціальну та економічну ситуацію в сільській місцевості[6].

2019-2028роки Організація Об'єднаних Націй оголосила Десятиліттям сімейних фермерських господарств i розробила загальний план дій, яким надає міжнародній спільноті докладні рекомендації з надання підтримки сімейним фермерським господарствам. Загальний план дій $\mathrm{OOH}$, що передбачає заходи на всіх рівнях - від місцевого до глобального, сформований за 7 взаємопов'язаними напрямками роботи:

1. Розвиток сприятливого політичного середовища для зміцнення сімейних фермерських господарств

2. Підтримка молоді й забезпечення стійкості сімейних фермерських господарств з покоління в покоління

3. Сприяння досягненню гендерної рівності в сімейних фермерських господарствах

4. Зміцнення організацій сімейних фермерських господарств

5. Підвищення стійкості сімейних фермерських господарств до зовнішніх впливів 
6. Зміцнення сімейних фермерських господарств для забезпечення стійкості продовольчих систем до змін клімату

7. Підтримка багатоплановості сімейних фермерських господарств для впровадження соціальних інновацій, що сприяють територіальному розвитку і функціонуванню продовольчих систем, які забезпечують збереження біорізноманіття, навколишнього середовища і культури.

Відповідно до Концептуального визначення в Україні слід розробити концепцію розвитку фермерських господарств, сільськогосподарської кооперації та розвитку сільськогосподарської дорадчої служби на 2020 - 2030 роки.

Комплексний план просторового розвитку об'єднаних територіальних громад повинен дорожньою картою розвитку сільських територій.

Вирішення проблем розвитку сільських територій мають включати наступні заходи: формування нормативно-правової бази в сфері зайнятості сільського населення, створення потужної дорадчої служби, професійно-освітню підготовку кадрів яка підвищить якість робочої сили, що дозволить зберегти і створити нові робочі місця, сприятиме розвитку підприємництва та самостійної зайнятості населення. У різних регіонах України можна розвивати різні види народних промислів та туристичного відпочинку і рекреації, зокрема, для ОСГ можна рекомендувати: екологічний (зелений) туризм, розвиток якого є особливо актуальним у всіх регіонах України, гастрономічний та тематичний сільський туризм, рекреаційний туризм (туризм 3 метою оздоровлення і лікування, відновлення фізичних та психологічних сил), апітуризм тощо. Всі ці заходи мають бути відображенні в комплексних планах просторового розвитку об'єднаних територіальних громад.

Висновок: Враховуючи кризові явища сільських територій, нераціональне та неефективне використання земель сільськогосподарського призначення, ліквідація Міністерства аграрної політики України спонукають до проведення заходів державного регуляторного впливу. У Конституцію України ввести розділ «Основи аграрного та земельного устрою України», визначивши основою земельного та аграрного устрою України сільськогосподарські кооперативи, фермерські та особисті селянські господарства, як основу відновлення сільських територій. При розміщенні об’єктів переробки сільського господарської продукції в сільській місцевості створити сприятливі умови для їх розвитку та створення нових робочих місць. Необхідно встановити граничні максимальні розміри земельних ділянок сільськогосподарського призначення, що може набуватися у власність однією особою, згідно європейських практик. Тому невідкладним завданням для уряду є перехід до реальної політики стимулювання багатоукладного та сталого розвитку українського села.

\section{Джерела та література}

1. Закон Про регулювання містобудівної діяльності https://kodeksy.com.ua/pro_regulyuvannya mistobudivnoi diyal_nosti/statja-1.htm

2. Закон України Про землеустрій// Відомості Верховної Ради України , 2003, № 36, ст.282

3. Земельний кодекс України// Відомості Верховної Ради України , 2002, № 3-4, ст.27)

4. Шворак А.М. Комплексний проект впорядкування території сільської (селищної) ради. Вісник №2 ЛДАУ , 1998. С.107-110.

5. Council Directive 91/676/EEC of 12 December 1991 concerning the protection of waters against pollution caused by nitrates from agricultural sources [Електронний pecypc] / Режим доступу: http://eur-lex.europa.eu/legalcontent/EN/TXT/?uri=CELEX:31991L0676.

6. Шворак А. М. Природні кормові вгіддя та соціально-економічний розвиток сільських територій. Економічний часопис Східноєвропейського національного університету імені Лесі Украӥнки : журнал / уклад. Л. Г. Ліпич, М. Б. Кулинич. - Луцьк : Вежа-Друк, 2018. - № 2 (14). - С. 112 - 116.

\section{References}

1.The law On the regulation of Urban Planning Activities

https://kodeksy.com.ua/pro_regulyuvannya_mistobudivnoi_diyal_nosti/statja-1.htm

2.The law of Ukraine About Land Management//Information Parliamentary, 2003, №36, article 282

3.The Law Code| of Ukraine//Information Parliamentary|, 2002, №3-4, article 27 
4.Shvorak A.M. The complex project of regulation of rural (village) Council territory/ A.M. Shvorak// Journal №2 LSAU, 1998.-Page 107-110.

5.Council Directive 91/676/EEC of 12 December 1991 concerning the

protection of waters against pollution caused by nitrates from agricultural sources [Електронний ресурс] / Режим доступу: http://eur-lex.europa.eu/legal-content/EN/TXT/?uri=CELEX:31991L0676.

6. Shvorak A.M. Natural feed grounds and social-economic development of rural territories. Economic Journal of East European National University named after Lesia Ukrainka: Journal/comp. L.G. Lipych, M.B. Kulynych. - Lutsk: Vezha-Druk, 2018. - №2(14). - Page 112-116.

Стаття надійшла до редакції 01.03.2020 р. 